\title{
Phytosociological approach to scree and ravine forest vegetation in Slovakia
}

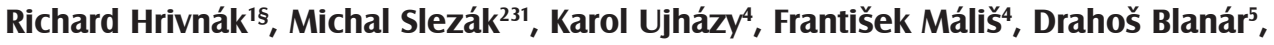 \\ Mariana Ujházyová6, Ján Kliment ${ }^{7}$
}

Hrivnák R., Slezák M., Ujházy K., Máliš F., Blanár D., Ujházyová M., Kliment J., 2019. Phytosociological approach to scree and ravine forest vegetation in Slovakia. Ann. For. Res. 62(2): 183-200.

Abstract. The aim of the study was to perform phytosociological revision of the scree and ravine forest vegetation in Slovakia in order to identify i) basic vegetation units according to their floristic composition, and ii) to find out the main environmental gradients affecting their compositional variability. Relevés originally assigned to broadly comprehended alliance Tilio platyphylli-Acerion ( 974 relevés) were used for the analyses. In order to select final dataset (527 relevés), formal criteria, such as tree layer cover $>50 \%$, relevé area of $200-500 \mathrm{~m}^{2}$ and presence at least two from six traditionally accepted diagnostic species of the alliance in Central Europe (Acer platanoides, Lunaria rediviva, Phyllitis scolopendrium, Polystichum aculeatum, Tilia platyphyllos and Ulmus glabra) were applied to the primal dataset. Altitude, aspect, slope, climatic characteristics (mean annual precipitation and air temperature), geological bedrock and Ellenberg indicator values (EIVs) were specified for each phytosociological relevé. We used modified TWINSPAN algorithm for classification, Detrended Correspondence Analysis (DCA) for explanation of species composition-environmental relationships, and both ANOVA corrected using modified permutation test and Mann-Whitney U-test to test environmental differences at each step of division by numerical classification. Two alliances, Melico-Tilion platyphylli and Tilio platyphylli-Acerion were distinguished with three (Aceri platanoidis-Tilietum platyphylli, Scolopendrio-Fraxinetum and Seslerio heufleranae-Quercetum petraeae) and two (Mercuriali perennis-Fraxinetum excelsioris and Lunario redivivae-Aceretum pseudoplatani) associations, respectively. Besides the floristic composition, other important factors for differentiation of the associations were altitude and related climatic characteristics. The main environmental characteristics affecting the overall compositional variability of studied forests were EIVs for light, moisture, soil reaction and temperature. The complex syntaxonomical revision identified five floristically and ecologically clearly differentiated associations, what reduced the number to almost half of previously distinguished communities from the territory of Slovakia. Moreover, presented concept is at alliance level in accordance with recent European classification approach.

Keywords: Carpathians, Melico-Tilion platyphylli, syntaxonomy, Tilio platyphylli-Acerion

Authors. 'Institute of Botany, Plant Science and Biodiversity Center, Slovak Academy of Sciences, Dúbravská cesta 9, SK-845 23 Bratislava, Slovakia | 
${ }^{2}$ Podtatranské Museum in Poprad, Vajanského 72/4, SK-058 01 Poprad, Slovakia ${ }^{3}$ Institute of Forest Ecology, Slovak Academy of Sciences, L. Stúra 2, SK-960 53 Zvolen, Slovakia | ${ }^{4}$ Department of Phytology, Faculty of Forestry, Technical University in Zvolen, T. G. Masaryka 24, SK-960 53 Zvolen, Slovakia $\mid{ }^{5}$ State Nature Conservancy, National Park Administration of the Muránska planina National Park, J. Král'a 12, SK-050 01 Revúca, Slovakia | ${ }^{6}$ Department of Applied Ecology, Faculty of Ecology and Environmental Sciences, Technical University in Zvolen, T. G. Masaryka 24, SK-960 53 Zvolen, Slovakia | ${ }^{7}$ Botanical Garden, Comenius University in Bratislava, Blatnica 315, SK-036 15 Blatnica, Slovakia

§Corresponding author: Richard Hrivnák (richard.hrivnak@savba.sk)

Manuscript received August 12, 2019; revised September 6, 2019; accepted September 13, 2019; online first November 29, 2019.

\section{Introduction}

Broadleaved scree and ravine forests form natural forest vegetation on specific habitats (ravines, rocky slopes and cliffs) with characteristic soil, topographic and climatic conditions. In Central Europe, they settle skeletal and shallow soils on various geological bedrocks in wide range of altitudes. These forest stands have high biodiversity conservation value because many of them are still preserved in natural state. They vary in number of vascular plant species, i.e. both species-poor and species-rich stands could be found (Baran et al. 2018). Forest overstorey is usually composed of nutrient-demanding trees like Acer platanoides, $A$. pseudoplatanus, Fraxinus excelsior, Tilia cordata, T. platyphyllos and Ulmus glabra. These dominant trees, commonly occur with other tree species, particularly Carpinus betulus, Quercus petraea agg., Fagus sylvatica, Abies alba and Picea abies reflecting the altitudinal gradient and presence of adjacent zonal vegetation. Herb layer consists mainly of nitrophilous and mesotrophic forest plants accompanied by numerous ferns adapted to different disturbance level as a consequence of less stable rocky substrates (Willner \& Grabherr 2007, Ellenberg 2009, Chytrý 2013). Characteristic (unique) species exclusively related to these vegetation units are relatively rare due to sharing of many understorey species with zonal broadleaved forests (Chytrý \& Tichý
2003, Willner \& Grabherr 2007, Jarolímek \& Šibík 2008, Kącki et al. 2013). Therefore, their classification at association and alliance level is highly variable among Central European regions.

Ravine and scree forests distributed across entire nemoral zone of the temperate Europe are traditionally classified within the order Fagetalia sylvaticae or recently within the order Aceretalia pseudoplatani (e.g. Rodwell 1991, Dierssen 1996, Willner \& Grabherr 2007, Košir et al. 2008, Paal 2009, Campos et al. 2011, Vukelić 2012, Mucina et al. 2016, Novák et al. 2017). Biogeographical and climatic gradients promote delimitation of two alliance groups within the Aceretalia pseudoplatani order, i.e. cool temperate and submediteranean group with two and three alliances, respectively (Mucina et al. 2016). Scree and ravine forests of subcontinental part of Central Europe refer to the Melico-Tilion platyphylli and Tilio platyphylli-Acerion alliances within the cool temperate group. In Central Europe, authors of vegetation surveys preferred rather broadly conceived concept of a single alliance Tilio platyphylli-Acerion (Pott 1992, Willner \& Grabherr 2007, Jarolímek \& Šibík 2008, Onyschenko 2010, Borhidi et al. 2012, Chytrý 2013, Matuszkiewicz 2014). It includes both termophilous and montane forest types. In addition, Illyrian ravine and scree forests recorded in Hungary were assigned to regionally specific suballiance Polysticho setiferi-Acere- 
nion psedoplatani (Aremonio-Fagion alliance; Borhidi et al. 2012).

In Slovakia, scree and ravine forests are developed on habitats with various environmental conditions in two contrasting climatic regions. While the southern Pannonian part of the country is affected by warm and dry subcontinental climate, the northern Carpathian regions are characterized by wet and montane subcontinental to suboceanic climate (Miklós 2002). The first phytosociological relevés of these specific forest stands were published in the 1930-40s (e.g. Klika 1936, 1941), but much more data have been recorded primarily in the last 40 years (e.g. Fajmonová 1973, Jurko 1975, Šomšák \& Háberová 1979, Kliment et al. 2010). They are distributed almost across all mountain ranges, with more abundant subsets available from central and western Carpathian regions. Seven to ten associations of the Tilio-Acerion alliance were reported in previous lists of vegetation units in Slovakia following expert-based classification approach (Mucina \& Maglocký 1985, Berta 1986, Jarolímek \& Šibík 2008), but some of them were mentioned only in a single survey. However, complex revision using a large phytosociological dataset and numerical methods had

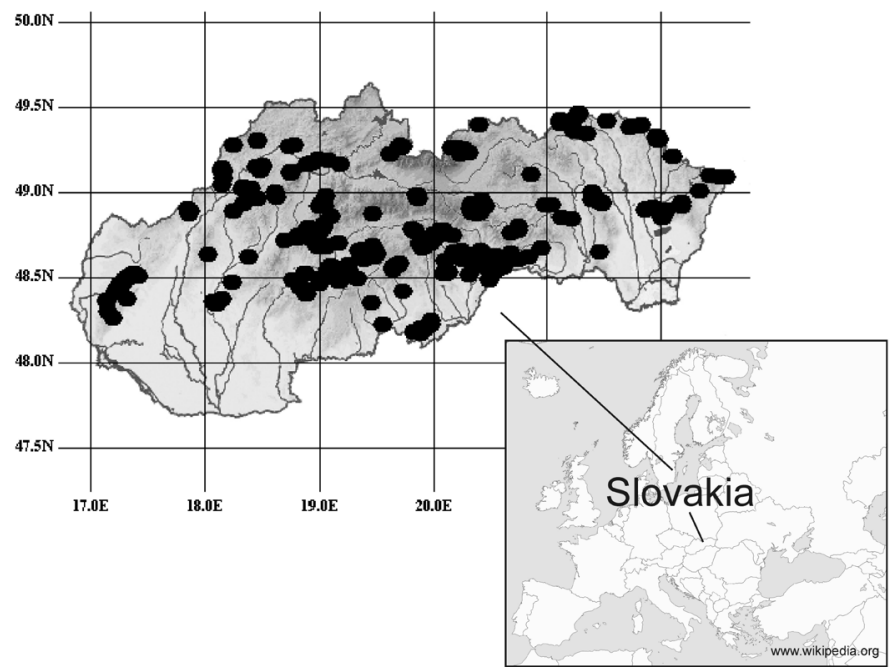

Figure 1 Map of the studied area not been realized yet. Such a revision is also essential to verify and apply the current classification concept of European vegetation at alliance level (Mucina et al. 2016). Therefore, our study aimed to perform a missing complex phytosociological revision and identify i) basic vegetation units of the scree and ravine forests in Slovakia based on their floristic composition and ii) the main environmental gradients affecting the compositional variability of these types of vegetation.

\section{Materials and methods}

Our study was realized in the territory of Slovakia (Central Europe; Figure 1). Phytosociological relevés were obtained from the Central Database of Phytocenological Relevés of Slovakia (644 relevés; code EU-SK-001 in the Global Index of Vegetation-Plot Databases, Šibík 2012) and from authors' unpublished material (330 relevés), all assigned into Tilio-Acerion sensu lato (including Melico-Tilion and Tilio-Acerion sensu Mucina et al. 2016). Initial set of 974 relevés was stored in Turboveg software (Hennekens \& Schaminée 2001) and further analysed in the Juice program (Tichý 2002). The dataset was corrected using two criteria. Firstly, only relevés with tree layer cover $>50 \%$ and those of area between 200-500 $\mathrm{m}^{2}$ were considered (dataset reduced to 874 relevés). Secondly, six diagnostic species (Acer platanoides, Lunaria rediviva, Phyllitis scolopendrium, Polystichum aculeatum, Tilia platyphyllos and Ulmus glabra) reported in Central European literature sources for Tilio-Acerion sensu lato (Chytrý \& Tichý 2003, Willner \& Grabherr 2007, Jarolímek \& Šibík 2008, Kącki 
et al. 2013) were used to identify relevés with significant afinity to this vegetation unit. At least two of these species would have to be present in the individual relevé. The final dataset thus contained 527 relevés, which were satisfactorily distributed across Slovakia (Figure 1). Species nomenclature and taxonomy were unified using broader defined plant taxa (Supporting information 1). For the next analyses, all records of juvenile trees occurring in herb layer were deleted, while trees in tree and shrub layers were combined into one taxon (see Chytrý 2013, Fischer 2015). Multiple records of shrubs (in shrub and herb layer) were similarly merged into one taxon. Plant taxa determined only to genera level and also bryophytes were omitted prior to all analyses. Although bryophytes were not recorded for each relevé, they were re-introduced in the final synoptic table (Chytrý 2013).

Modified TWINSPAN algorithm (Roleček et al. 2009) was run for numerical classification with two pseudospecies cut levels $(0 \%, 50 \%)$ and total inertia as a measure of cluster heterogeneity. At first, we divided data set into two main groups corresponding to two alliances sensu Mucina et al. (2016). Then we classified each group individually with the same TWINSPAN setting described above. Differential species of each cluster were determined using frequency and fidelity thresholds $(\Phi-$ phi coefficient; Chytrý et al. 2002). Fidelity calculation was based on the presence/absence data with a standardization of relevé groups to an equal size. The Fisher's exact test $(p<0.05)$ was used to eliminate species with non-significant occurrence optimum in a particular cluster (Tichý \& Chytrý 2006). Diagnostic species were defined as species showing simultaneously frequency $\geq 20 \%$, the phi coefficient $\geq 0.25$ and the difference in frequencies among clusters $>20 \%$. If a particular species was constant (frequency $\geq 50 \%$ ) in two or more clusters, it was not accepted as diagnostic. Fidelity and frequency values of bryophytes were derived only from the subset of 205 relevés with their records.
The main environmental gradients responsible for compositional variability of vegetation were analysed using Detrended Correspondence Analysis (DCA) in Canoco for Windows package (ver. 5.0; ter Braak \& Šmilauer 2012). DCA ordination was performed with detrending by segments, logarithmic transformation of species cover values and downweighting of rare species. The main source of variation in species composition was interpreted by unweighted means of Ellenberg indicator values for vascular plants (EIVs; Ellenberg et al. 1992). Multiple linear regression with modified permutation test (999 permutations; Zelený \& Schaffers 2012) was performed to test associations between EIVs and the first two DCA ordination axes using R 3.0.1 software ( $\mathrm{R}$ Core Team 2013). Some other environmental variables were recorded in the field by authors (altitude, aspect and slope) or obtained from GIS (climatic data and the type of geological bedrock). Climatic data represented by mean annual precipitation and temperature (records from the period 1961-1990) were provided by the Slovak Hydrometeorological Institute. Geological bedrock for each plot was obtained from Geological maps of Slovakia (1: 50 000). Both were derived from raster values computed in GRASS GIS (Grass Development Team, 2010). Geological bedrock and cover of particular layers were used only to describe the vegetation units. Differences in the values of EIVs and measured factors (altitude, mean annual precipitation and temperature) at each step of division by numerical classification (modified TWINSPAN algorithm) were tested with ANOVA corrected using modified permutation test and Mann-Whitney U-test, respectively. Distribution maps of vegetation units were created by DMAP software (Morton 2005).

Nomenclature of plant species and communities was used according to Marhold \& Hindák (1998), Mucina et al. (2016) and Jarolímek \& Šibík (2008). The nomenclatural revision of the particular vegetation units was 
done according to the rules of the International Code of Phytosociological Nomenclature (ICPN; Weber et al. 2000).

\section{Results}

\section{Numerical classification}

The whole dataset of scree and ravine forest vegetation was split into two floristically well-established groups of relevés (Supporting information Table 1). Altitude and related climatic characteristics (mean annual temperature and precipitation) accompanied by EIV for light and nutrients were the key factors affecting the divisions (all $\mathrm{p}<0.05$; Figure 2).
In the first group (Melico-Tilion platyphylli), the first division was ecologically well defined, with significant differences in altitude, climatic factors, EIV for continentality, light and nutrients (all $\mathrm{p}<0.05$ ). Further level of division was less pronounced with marginal effect of mean annual precipitation $(\mathrm{p}=0.065)$. The first division of the second group (Tilio platyphyl$l i$-Acerion) was driven by the altitude and climatic characteristics (all $\mathrm{p}<0.05$; Figure 2).

\section{Ordination analysis}

Detrended correspondence analysis (DCA) showed relatively clear differentiation of distinguished vegetation units (Figure 3a). Based

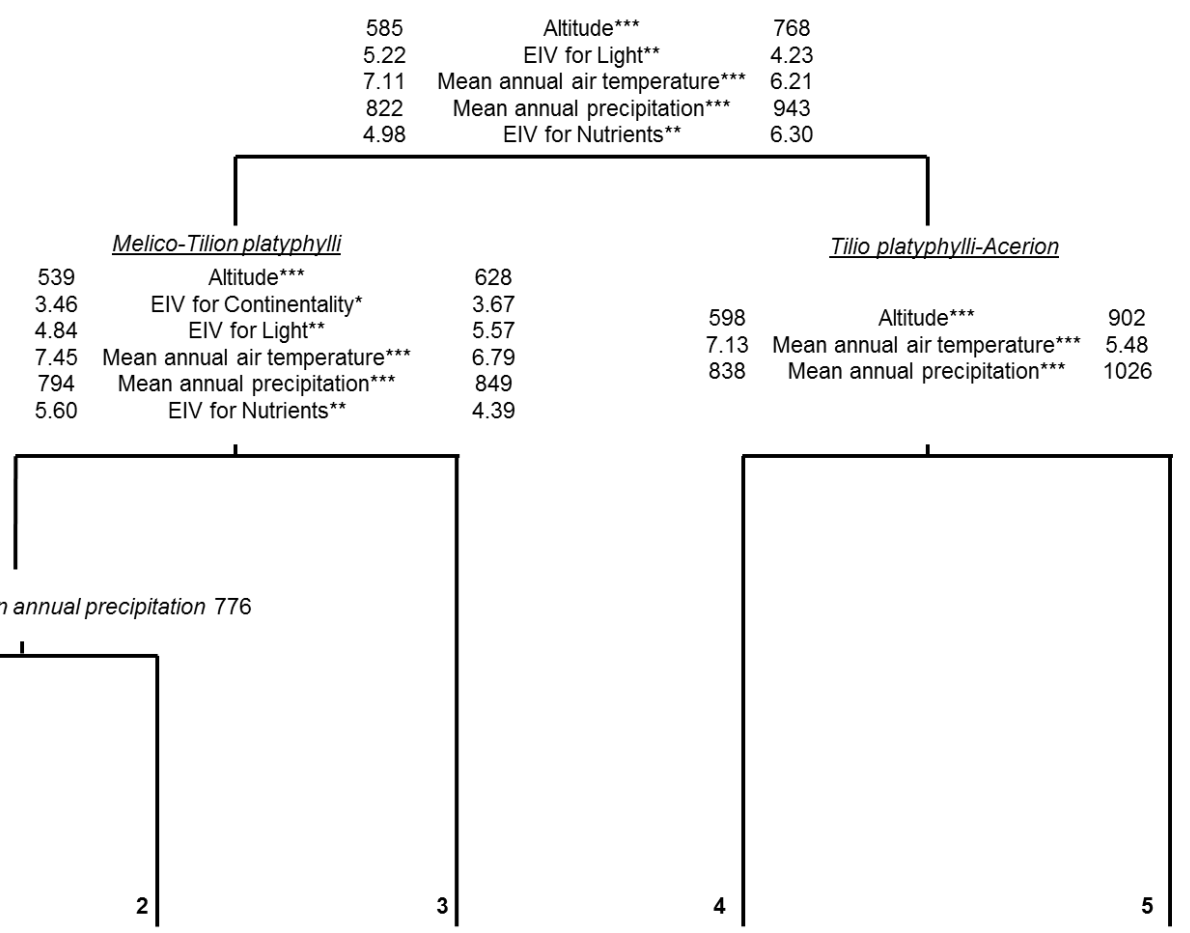

Figure 2 Dendrogram of numerical classification with environmental differences between two clusters at each step of division. Only statistically significant variables are shown, in alphabetically order, together with their median values $(* p<0.05$; ** $p<0.01$; *** $p<0.001$; without any symbol $\mathrm{p}=0.065)$. The number of clusters correspond with the synoptic tables Table 2 and Table 3 (1 - Aceri platanoidisTilietum platyphylli, 2 - Scolopendrio-Fraxinetum, 3 -Seslerio heufleranae-Quercetum petraeae, 4 - Mercuriali perennis-Fraxinetum excelsioris, 5 - Lunario redivivae-Aceretum pseudoplatani) 


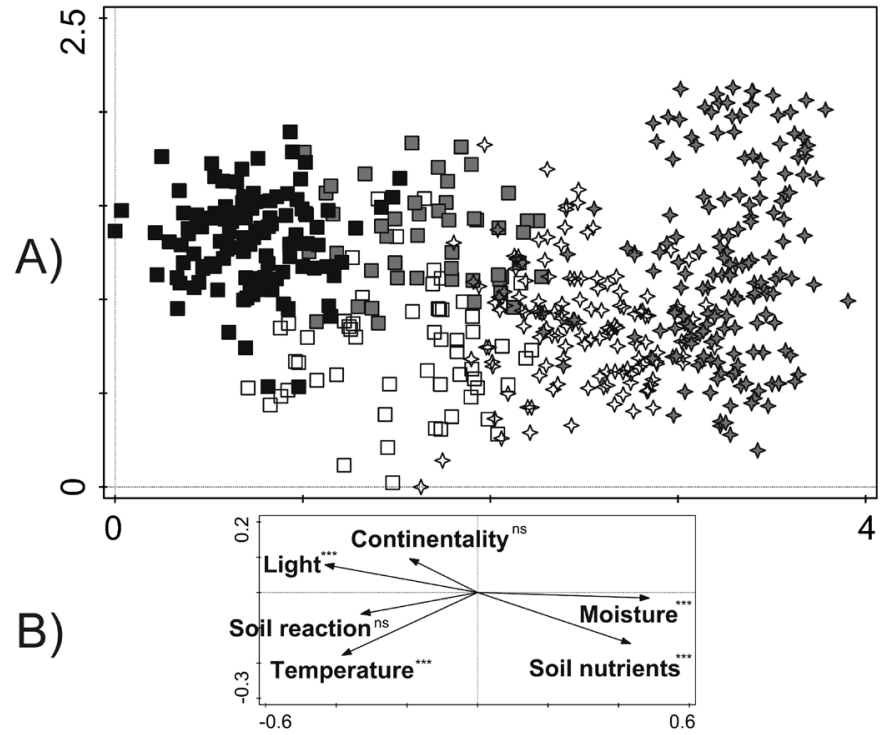

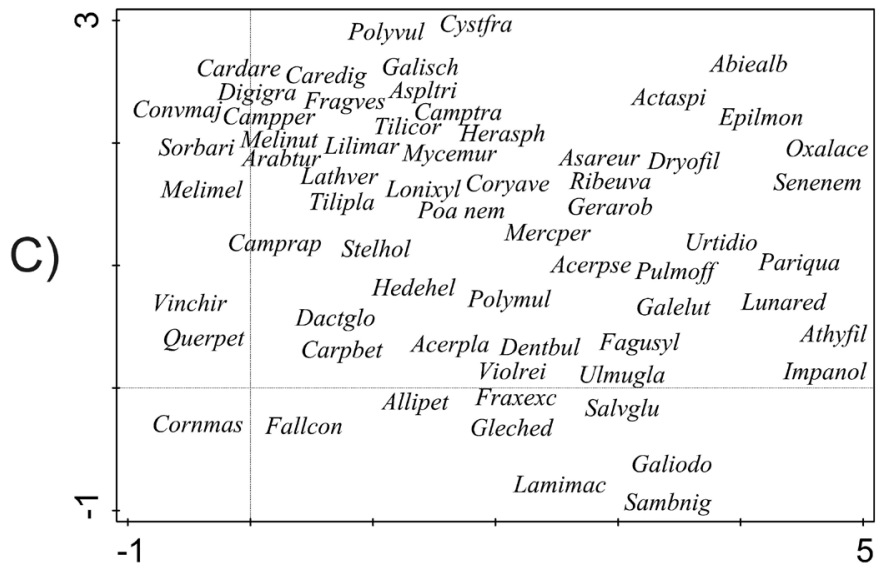

Figure 3 DCA: sample, environmental and species plots of ravine and scree forests in Slovakia. A - sample plot (squares = Melico-Tilion platyphylli, empty = Aceri platanoidis-Tilietum platyphylli, shade $=$ Scolopendrio-Fraxinetum, black = Seslerio heufleranae-Quercetum petraeae; stars = Tilio platyphylli-Acerion, empty = Mercuriali perennis-Fraxinetum excelsioris and shade =Lunario redivivae-Aceretum pseudoplatani), B - Ellenberg indicator values as supplementary variables and $\mathrm{C}-$ species plot (only species with constancy higher than $20 \%$ in whole data set are displayed. For abbreviations of plant taxa see Supporting information 3 .

on EIVs, the main ecological gradients affecting the compositional variability of these forests were EIVs for light, moisture, soil re- action and temperature (all $p<0.001$; Figure 3b). Plant species turnover followed these gradients and were arranged from thermophilous and heliophilous plants growing on the soils with relatively low amount of nutrients (e.g. Cornus mas, Melittis melisophyllum, Sorbus aria, Vincetoxicum hirundinaria) to eutrophic and/or moisture demanding species of cool sites (e.g. Abies alba, Impatiens noli-tangere, Senecio nemorensis agg.; Figure 3c).

\section{Description of vegetation units}

Syntaxonomical interpretation of confirmed vegetation units is in accordance with previously described syntaxa from Central European region. Three associations were assigned to the alliance $\mathrm{Mel}$ ico-Tilion platyphylli (Supporting information Table 1, column 1; Supporting information Table 2) and two associations to the alliance Tilio platyphylli-Acerion (Supporting information Table 1, column 2; Supporting information Table 3).

Melico-Tilion platyphylli Passarge et G. Hofmann 1968 (Supporting information Table 1, column 1; Supporting information Table 2). Thermophilous lime forests on scree slopes at low altitudes of the southern regions of Central Europe. Syn.: Melico-Tilion platyphylli Passarge 1968 (§ 33), Tilion Moor 1973 (§ 
29c). Incl.: Tilienion platyphylli (Moor 1973) Müller in Oberdorfer 1992. Nomenclatural type: Aceri-Tilietum Faber 1936 (Willner 2015, lectotype).

Tree layer (mean cover $\sim 78 \%$ ) is created mainly by broadleaved species Acer platanoides, Carpinus betulus, Tilia platyphyllos, T. cordata with co-occurrence of Fraxinus excelsior, Quercus petraea agg. or Sorbus aria. The most frequent shrubs (mean cover $\sim 12 \%$ ) are Cornus mas and Corylus avellana. Mesotrophic species, which are frequent in oak and oak-hornbeam forests (Campanula rapunculoides, Convallaria majalis, Galium schultesii, Mycelis muralis, Vincetoxicum hirundinaria), commonly occur together with nitrophilous species (Alliaria petiolata, Campanula trachelium, Geranium robertianum, Mercurialis perennis) and ferns (e.g. Asplenium trichomanes). Herb layer is relatively open (mean cover $\sim 56 \%$ ). Constant species of well-developed moss layer (constancy $>50 \%$ ) are Anomodon viticulosus, Hypnum cupressiforme, Porella platyphylla and Tortella tortuosa.

These forest stands occur mainly on limestones. They prefer steep (mean $\sim 30^{\circ}$ ) rocky slopes with various aspects in hilly regions (mean altitude $\sim 517 \mathrm{~m}$ a.s.l., mean precipitation $\sim 822 \mathrm{~mm}$ and temperature $\sim 7.1^{\circ} \mathrm{C}$, Figure 4).

Aceri platanoidis-Tilietum platyphylli Faber 1936 (Supporting information Table 2, column 1). Original form of the name: Assoziation Acereto-Tilietum (Faber 1936). Syntax. syn.: Aceri-Carpinetum Klika 1941; Roso pendulinae-Tilietum cordatae Csiky et al. 2001. Incl.: Aceri-Carpinetum aconitetosum vulpariae Husová 1982. Pseud.: Mercuriali-Tilietum Zólyomi et Jakucs ex Fekete et Járai-Komlódi 1962 (Háberová et al. 1985 p.p.), Vincetoxico-Tilietum auct. non Winterhoff 1963 (e. g. Jurko 1975 p. p.). Nomenclatural type: Faber 1936, Table 6, column B1, rel. 1 (Willner 1996, lectotype).

The canopy-closed tree layer (cover $\sim 80 \%$ ) is dominated mainly by Tilia platyphyllos, less frequently by Acer platanoides, Fagus sylvat- ica, Fraxinus excelsior, Quercus petraea agg. and occasionally by Acer pseudoplatanus, Carpinus betulus and Tilia cordata. Other species (e.g. Acer campestre and Sorbus torminalis) usually occur with lower coverage. In the shrub layer (mean cover $\sim 15 \%$ ), Cornus mas shows the highest frequency and cover, while Corylus avellana, Crataegus laevigata and Sambucus nigra are less frequent. Constant species of the herb layer are mainly mesotrophic (Campanula rapunculoides, Galium odoratum, Lathyrus vernus, Melica uniflora, Mycelis muralis, Poa nemoralis) and nitrophilous plants (Alliaria petiolata, Galium aparine, Geranium robertianum, Glechoma hederacea agg., Mercurialis perennis). Several of them reach high cover values (e.g. Mercurialis perennis). The thermophilous species are rare, with exception of Vincetoxicum hirundinaria. Herb layer is relatively open ( 58\%). Only Hypnum cupressiforme and Anomodon viticulosus show high constancy and cover in the moss layer.

The association is recorded mainly on limestones, occasionally on volcanic or crystaline bedrock (e.g. basalt, andesite, diorite). The stands usually occur in hilly regions (altitude $\sim 517 \mathrm{~m}$ a.s.1.) on moderately steep $\left(\sim 28^{\circ}\right)$ rocky slopes indifferent to slope aspect, with mean precipitation and temperature of $\sim 809$ $\mathrm{mm}$ and $\sim 7.5^{\circ} \mathrm{C}$, respectively (Figure 4 ).

Distribution of the association is documented from foothills of the Western Carpathians, such as Malé Karpaty Mts, Zoborské vrchy Mts, Strážovské vrchy Mts, Cerová vrchovina Mts, Muránska planina Mts and Slovenský kras Mts (Figure 5).

Scolopendrio-Fraxinetum Schwickerath 1938 (Supporting information Table 2, column 2). Original form of the name: Scolopendrieto-Fraxinetum (Schwickerath 1938). Syn.: Phyllitido-Aceretum subcarpaticum Soó 1962 (§ 2b), Phyllitido-Aceretum subcarpaticum Soó ex Jakucs 1967 (§ 34a). Incl.: Phyllitido-Aceretum subcarpaticum anemonetosum ranunculoides Jakucs 1967. Non: Phyllitido-Acere- 

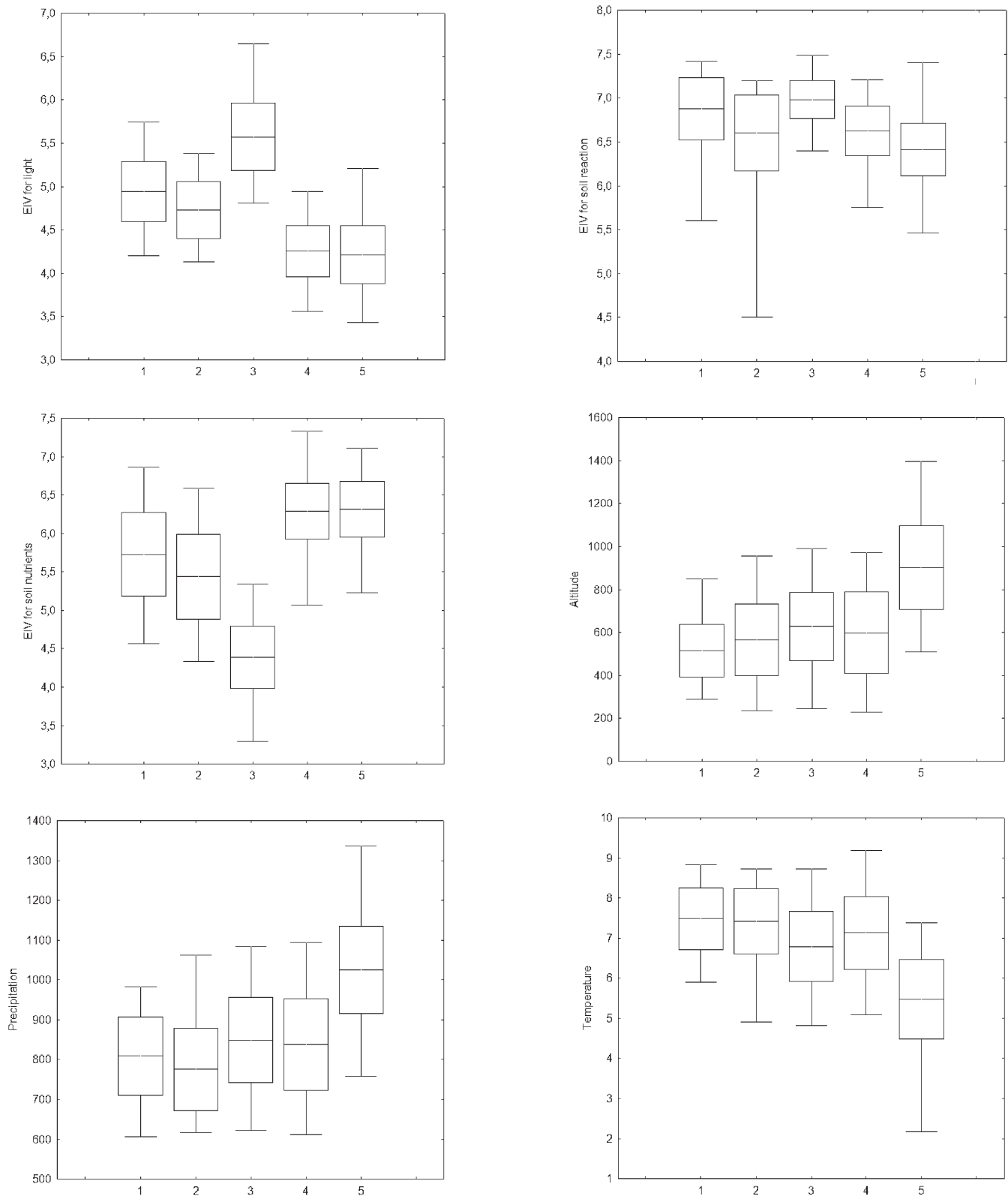

Figure 4 Box-plots of Ellenberg indicator values for light, soil reaction and nutrients, altitude, mean annual air temperature and precipitation. Horizontal line represents mean, box standard deviation of mean, whiskers minimum and maximum values. 1 - Aceri platanoidis-Tilietum platyphylli, 2 - Scolopendrio-Fraxinetum, 3 - Seslerio heufleranae-Quercetum petraeae, 4 -Mercuriali perennis-Fraxinetum excelsioris, 5 - Lunario redivivae-Aceretum pseudoplatani

tum Moor 1945 Pseud: Mercuriali-Tilietum Zólyomi et Jakucs ex Fekete et Járai-Komlódi
1962 (Háberová et al. 1985 p.p.). Nomenclatural type: Schwickerath 1938: 294-295, rel. 29, 
lectotype (Husová in Moravec et al. 2000).

The stands are usually four-layered. The canopy-closed tree layer $(\sim 82 \%)$ is created by combination of broadleaved deciduous trees, with Tilia platyphyllos as dominant tree, and Acer pseudoplatanus, A. platanoides, Carpinus betulus, Fagus sylvatica, Fraxinus excelsior and Quercus petraea agg. as co-occurring and locally dominant species. Other co-occuring tree species, such as Tilia cordata or Ulmus glabra do not usually reach higher cover values. Evenly developed shrub layer usually has low cover $(\sim 6 \%)$ and is frequently formed by Cornus mas, Corylus avellana and Ribes uva-crispa. The physiognomy of the herb layer (cover $\sim 55 \%$ ) is determined by mosaic of ferns (Asplenium trichomanes, Cystopteris fragilis, Dryopteris filix-mas, Phyllitis scolopendrium, Polypodium vulgare), nitrophilous (Alliaria petiolata, Geranium robertianum, Glechoma hederacea agg., Mercurialis perennis) and mesotrophic species (Asarum europaeum, Campanula rapunculoides, Galeobdolon luteum agg., Lathyrus vernus, Mycelis muralis and Poa nemoralis). Moss layer is well developed with high number of species, several of them with high constancy (e.g. Ctenidium molluscum, Homalothecium philippeanum, Plagiochila porelloides). The bryophytes create almost half of diagnostic species of the association (e.g. Anomodon attenuatus, Ctenidium molluscum, Homalothecium philippeanum) and they occur particularly on boulders.

This association inhabits mainly limestones, occasionally other bedrock types. It usually occurs in hilly regions (altitude $\sim 566 \mathrm{~m}$ ) with the mean precipitation of $\sim 776 \mathrm{~mm}$ and temperature of $\sim 7.4^{\circ} \mathrm{C}$ (Figure 4$)$. They were found on steep $\left(\sim 30^{\circ}\right)$, mostly northern and western slopes of ravines or at the foot of the rocky slopes.

The association is recorded mainly in the karst areas of the southern part of Slovakia (Slovenský kras Mts, Drienčanský kras Mts and Muránska planina Mts), rarely in other mountain ranges of the Western Carpathians (e.g. Strážovské vrchy Mts and Malé Karpaty
Mts; Figure 5).

Seslerio heufleranae-Quercetum petraeae Šomšák et Háberová 1979 (Supporting information Table 2, column 3). Original form of the name: Assoziation Seslerio heufleranae-Quercetum petraeae (Šomšák \& Háberová 1979). Syn.: Poo stiriacae-Tilietum Fajmonová in Háberová et al. 1985 prov. $(\S 1,3 b)$. Pseud.: Cynancho-Tilietum platyphylli auct. non Winterhoff 1963 (e.g. Fajmonová 1993), Mercuriali-Tilietum Zólyomi et Jakucs ex Fekete et Járai-Komlódi 1962 (Miadok 1981). Nomenclatural type: Šomšák \& Háberová 1979, Table 4, rel. 1, holotype.

Moderately closed tree layer (cover $\sim 75 \%$ ) is formed by a mixture of rather thermophilous species of lower altitudes (Carpinus betulus, Quercus petraea agg., Sorbus aria) and typical tree species of scree habitats (Acer platanoides, Fraxinus excelsior, Tilia cordata, T. platyphyllos). The most frequent dominant trees are Tilia platyphyllos and Quercus petraea agg.. The shrub layer (cover $\sim 13 \%$ ) is formed mainly by Cornus mas. In the species rich herb layer $(\sim 65$ species per relevé), occurs numerous thermophilous species such as Campanula persicifolia, Convallaria majalis, Digitalis grandiflora, Hylotelephium maximum, Laserpitium latifolium, Melittis melissophyllum, Polygonatum odoratum or Vincetoxicum hirundinaria. Some of them (e.g. Convallaria majalis and Vincetoxicum hirundinaria), as well as calciphilous grass Calamagrostis varia reach high cover values. In addition, other mesotrophic (e.g. Arabis turrita, Campanula rapunculoides, $C$. trachelium, Carex digitata, Galium schultesii, Lathyrus vernus, Mycelis muralis, Poa nemoralis), nitrophilous species (Mercurialis perennis - occasionally as dominant) and ferns (Asplenium trichomanes) are admixed. Bryophytes occur frequently (e.g. Anomodon viticulosus, Hypnum cupressiforme, Porella platyphylla and Tortella tortuosa).

Limestones are typical bedrock type for the association. Less frequent are dolomites or fluvial sediments. The stands occur in hilly and sub-montane regions (altitude $\sim 628 \mathrm{~m}$ a.s.1.), 


\section{Aceri platanoidis-Tilietum platyphylli}

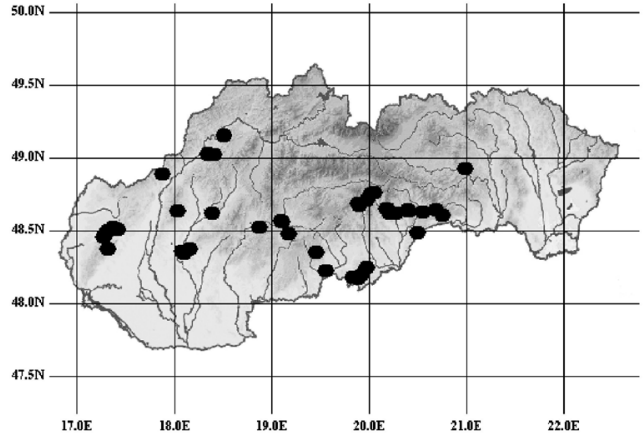

Seslerio heufleranae-Quercetum petraeae

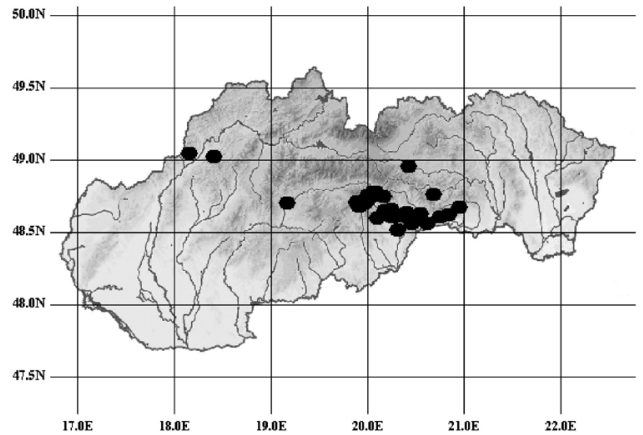

Scolopendrio-Fraxinetum

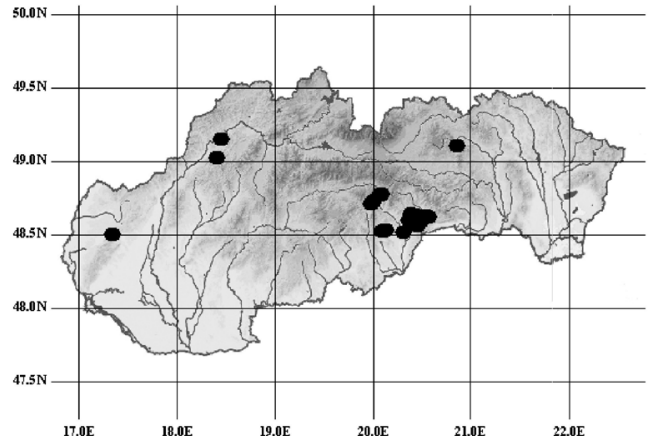

Mercuriali perennis-Fraxinetum excelsioris

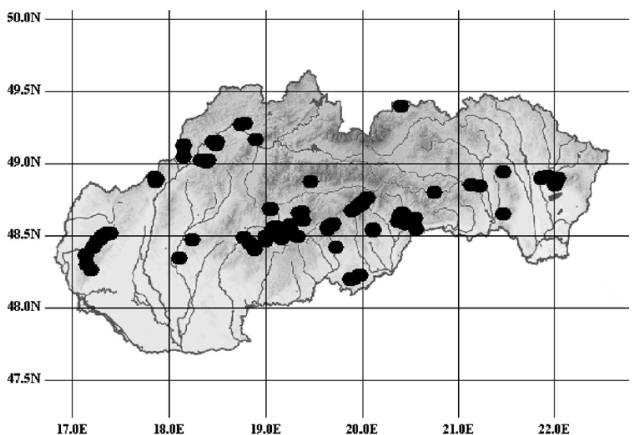

Lunario redivivae-Aceretum pseudoplatani

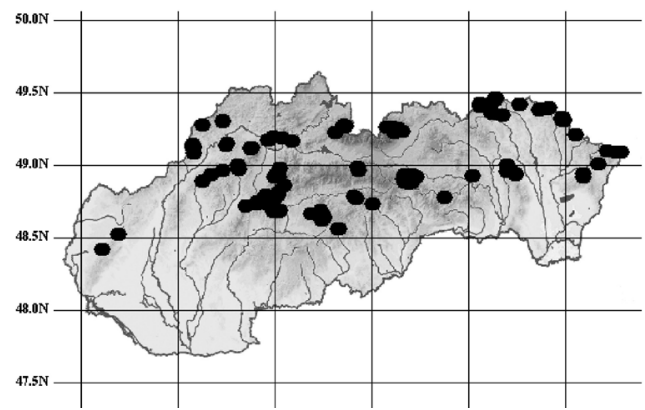

Figure 5 Distribution of the associations Melico-Tilion platyphylli and Tilio platyphylli-Acerion in Slovakia

mainly on steep slopes $\left(\sim 31^{\circ}\right)$ with various slope aspects, with mean precipitation of $\sim 849$ $\mathrm{mm}$ and temperature of $\sim 6.8^{\circ} \mathrm{C}$ (Figure 4 ).

Distribution of the association is concentrated to the Muránska planina Mts and Slovenský kras Mts, with rare occurrence in other karst regions (e.g. Biele Karpaty Mts and Mičiná karst; Figure 5).

Tilio platyphylli-Acerion Klika 1955 (Supporting information Table 1, column 2; Sup- 
porting information Table 3). Sycamore maple forests in the montane belt and cool ravines of the Central European mountain ranges. Original form of the name: Tilieto-Acerion fed. $\mathrm{n}$. (Klika 1955). Syntax. syn.: Lunario-Acerion Moor 1973. Incl.: Acerenion pseudoplatani Oberdorfer 1957 p. p. (typo excl.); Lunario-Acerenion pseudoplatani (Moor 1973) Müller in Oberdorfer 1992. Nomenclatural type: Aceretum pseudoplatani Fatrae Klika 1936, lectotype (Husová 1973).

The canopy of tree layer is almost closed $(\sim 80 \%)$ and created mainly by Acer pseudoplatanus and Fagus sylvatica with the co-occurrence of Acer platanoides, Fraxinus excelsior and Ulmus glabra. The shrub layer is poorly developed with very low cover $(\sim 8 \%)$. Physiognomy of the herb layer (cover $\sim 68 \%$ ) is determined by upper layer of ferns (Dryopteris filix-mas) and high herbs (Impatiens noli-tangere, Lunaria rediviva, Senecio nemorensis agg., Urtica dioica) which is undergrown by lower herb species (Galeobdolon luteum agg., Galium odoratum, Geranium robertianum, Mercurialis perennis, Mycelis muralis, Oxalis acetosella, Pulmonaria officinalis agg.). Species composition consists of a combination of nitrophilous and mesotrophic plants. Moss layer is well developed, covering stones, boulders and dead wood. Species Ctenidium molluscum, Eurhynchium angustirete, Plagiomnium undulatum and Rhizomnium punctatum occur with constancy higher than $20 \%$.

Communities of the alliance are present mainly on carbonates, volcanic and occasionally also on crystaline bedrock. These forest stands prefer moderately steep $\left(\sim 26^{\circ}\right)$ rocky slopes in montane regions (altitude $\sim 767 \mathrm{~m}$ a.s.1.) with mean precipitation and temperature of $\sim 943$ $\mathrm{mm}$ and $\sim 6.2{ }^{\circ} \mathrm{C}$, respectively (Figure 4 ).

Mercuriali perennis-Fraxinetum excelsioris (Klika 1942) Husová in Moravec et al. 1982. (Supporting information Table 3, column 1). Original form of the name: Mercuriali-Fraxinetum (Klika 1942) Husová nom. nov. (Husová in Moravec et al. 1982). Syn. (basionym): Acereto-Fagetum (carpaticum)
Klika 1942 (§ 34a). Non: Aceri pseudoplatani-Fraxinetum Rübel 1930. Phantom name: Mercuriali-Fraxinetum (Klika 1942) Husová 1981 (Wallnöfer et al. 1993; Ujházyová 2007). Nomenclatural type: Klika 1942: 18-19, rel. 5, lectotype (Husová in Moravec et al. 2000).

The stands of this association are mostly three- (four-) layered. Diverse tree layer is formed by mixture of various broadleaved deciduous trees. High constancy and cover show Acer pseudoplatanus, A. platanoides, Fagus sylvatica and Fraxinus excelsior. In addition, other tree species, such as Carpinus betulus, Tilia platyphyllos, T. cordata and Ulmus glabra are admixed. Shrub layer is rarely developed, with a rather low cover $(\sim 8 \%)$, created mostly by young individuals of tree species. They are accompanied by mesotrophic and nitrophilous shrubs (Corylus avellana and Sambucus nigra). The species-rich herb layer with cover $\sim 61 \%$ is formed particularly by numerous nitrophilous (Actaea spicata, Alliaria petiolata, Chelidonium majus, Geranium robertianum, Glechoma hederacea agg., Impatiens noli-tangere, Lunaria rediviva, Mercurialis perennis, Urtica dioica) and mesotrophic herbs (Asarum europaeum, Galeobdolon luteum agg., Galium odoratum, Mycelis muralis, Polygonatum multiflorum, Pulmonaria officinalis) together with fern (Dryopteris filix-mas) and juvenile tree species (Acer platanoides, A. pseudoplatanus, Fagus sylvatica, Fraxinus excelsior). The moss layer is usually species rich, however, often reaches a low cover. Only Hypnum cupressiforme is regularly present, the constancy of other species is relatively low.

Most relevés were recorded on carbonate and volcanic (mainly andesites) bedrock, whereas another substrates were rare (e.g. granodiorites, sandstones). This plant community prefers moderately steep slopes $\left(\sim 28^{\circ}\right)$ in hilly and sub-montane regions (altitude $\sim 598 \mathrm{~m}$ a.s.1.) with mean precipitation and temperature of $\sim 838 \mathrm{~mm}$ and $\sim 7.1^{\circ} \mathrm{C}$, respectively (Figure 4).

The association is recorded mainly in the foothills of the Western Carpathians from Malé Karpaty Mts to Vihorlatské vrchy Mts (espe- 
cially in Malé Karpaty Mts, Strážovské vrchy Mts, Kremnické vrchy Mts, Javorie Mts, Veporské vrchy Mts, Slovenský kras Mts, Volovské vrchy Mts, and Vihorlatské vrchy Mts), only rarely in their central mountain ranges, e.g. Malá Fatra Mts and Nízke Tatry Mts (Figure 5).

Lunario redivivae-Aceretum pseudoplatani Klika 1936 nom. invers. propos. (Supporting information Table 3, column 2). Original form of the name: Acer pseudoplatanus-Lunaria rediviva-Assoziation (Klika 1936 as an alternative name). Syn.: Aceretum pseudoplatani Sillinger 1933 (§ 31); Aceretum pseudoplatani Fatrae Klika 1936 (§ 34a); Aceri-Fraxinetum Tüxen 1937 (§ 31); Acereto-Lunarietum Sillinger 1939 p. p. (§ 2b, 10b); Acereto-Fagetum (carpaticum) Klika 1942 p. p. (typo excluso) (§ 34a); Phyllitido-Aceretum Moor 1952 (§ 31); Lunario-Aceretum Schlüter in Grüneberg et Schlüter 1957 (§ 31), Lunario-Aceretum pseudoplatani prov. Hadač et al. 1969 (§ 3b). Syntax. syn.: Phyllitido-Aceretum Moor 1945; Arunco-Aceretum Moor 1952; Lunario-Abietetum Fajmonová 1984; Tilio cordatae-Abietetum Šomšák 1992. Incl.: Aceretum pseudoplatani, Lunaria-type Sillinger 1933; Fraxino-Fagetum lunarietosum Klika 1942; Fagetum carpaticum Walas 1933 phyllidetosum Kučerová et Jeník 1963 prov. (čl. 3b); Scolopendrio-Fraxinetum cystopteridetosum montanae Fajmonová 1985. Pseud.: Aceri-Fraxinetum auct. non Rübel 1930 (Fajmonová 1973, 1974, 1980). Non: Scolopendrio-Fraxinetum Schwickerath 1938. Nomenclatural type: Klika 1936, Table VII, rel. 31, lectotype (Husová 1973 for Aceretum pseudoplatani fatrae Klika 1936).

These stands are usually three layered with moderately closed canopy $(\sim 77 \%)$. Tree layer is almost exclusively created by dominant species Acer pseudoplatanus and Fagus sylvatica. They are accompanied by other broadleaved (e.g. Acer platanoides, Fraxinus excelsior, Ulmus glabra) and coniferous tree species (Abies alba and Picea abies). The shrub layer is poorly developed, with very low cover values 194 $(\sim 3 \%)$ and mostly formed by the juvenile tree species. The physiognomy of the herb layer (cover $\sim 74 \%$ ) is usually determined by nitrophilous (Geranium robertianum, Lunaria rediviva, Mercurialis perennis, Urtica dioica), and mesophilous herbs (e.g. Actaea spicata, Asarum europaeum, Epilobium montanum, Galeobdolon luteum agg., Galium odoratum, Impatiens noli-tangere, Mycelis muralis, Oxalis acetosella, Pulmonaria officinalis agg., Salvia glutinosa, Senecio nemorensis agg.) and ferns (Athyrium filix-femina, Dryopteris filix-mas, rarely Cystopteris fragilis, Dryopteris carthusiana agg., Phyllitis scolopendrium, Polystichum aculeatum). Among mosses, Ctenidium molluscum, Eurhynchium angustirete, Plagiomnium undulatum, Rhizomnium punctatum and liverwort Conocephalum conicum frequently occur.

Stands of the association usually occur on carbonate and volcanic bedrock, occasionally on crystalline bedrock. They inhabit moderately steep $\left(\sim 26^{\circ}\right)$ rocky slopes of montane regions (altitude $\sim 902 \mathrm{~m}$ a.s.1.) with mean precipitation and temperature of $\sim 1026 \mathrm{~mm}$ and $\sim 5.5^{\circ} \mathrm{C}$, respectively (Figure 4 ).

They occupy suitable sites across the Western Carpathians (Biele Karpaty Mts, Javorníky Mts, Strážovské vrchy Mts, Malá Fatra Mts, Vel'ká Fatra Mts, Nízke Tatry Mts, Západné Tatry Mts, Belianske Tatry Mts, Busov Mts, Laborecká vrchovina Mts, Bukovské vrchy Mts, Kremnické vrchy Mts, Pol'ana Mts, Veporské vrchy Mts, Muránska planina Mts, Slovenský raj Mts and Slánske vrchy Mts ; Figure 5).

\section{Discussion}

Our comprehensive syntaxonomical revision introduced new phytosociological concept of scree and ravine forests in Slovakia. It suggested the delimitation of two floristically and ecologically well-differentiated alliances. The Melico-Tilion platyphylli alliance comprises scree and ravine forests at low and medium al- 
titudes, which is divided into three associations representing subxerophilous, mesophilous and thermophilous communities. Submontane and montane scree forests were classified into Tilio platyphylli-Acerion, and are represented by two associations. Although this synaxonomical structure contradicts the traditional classification of these forests in Slovakia within single alliance Tilio platyphylli-Acerion pseudoplatani (Jarolímek \& Šibík 2008), it corresponds with recently published classification of European vegetation (Mucina et al. 2016).

The proposed syntaxonomical synopsis of ravine and scree forests and their affiliation to the higher vegetation units in Slovakia is as follows: Class Carpino-Fagetea sylvaticae Jakucs ex Passarge 1968, Order Aceretalia pseudoplatani Moor 1976 nom. cons. propos. Alliance Melico-Tilion platyphylli Passarge et G. Hofmann 1968, Association Aceri platanoidis-Tilietum platyphylli Faber 1936, Association Scolopendrio-Fraxinetum Schwickerath 1938, Association Seslerio heufleranae-Quercetum petraeae Šomšák et Háberová 1979, Alliance Tilio platyphylli-Acerion Klika 1955, Association Mercuriali perennis-Fraxinetum excelsioris (Klika 1942) Husová in Moravec et al. 1982, Association Lunario redivivae-Aceretum pseudoplatani Klika 1936 nom. invers. propos.

It is highly expected that the scree and ravine forest communities have similar floristic composition over the regions of Central Europe. However, the patterns of syntaxonomical units in neighbouring countries do not necessarily reflect only phytogeographical and ecological gradients, but also different syntaxonomical approaches. The presented list of associations is mostly in accordance with the revised concept of the scree and ravine forest vegetation in the Czech Republic (Chytrý 2013). The Czech survey partially covers the region of the Western Carpathians and Pannonian lowland, as well. Included vegetation units are known from both countries and have similar floristic composition and ecology, with the exception of association Seslerio albicantis-Tilietum cordatae reported only from the Czech Republic. It represents lime dominated (Tilia cordata, T. platyphyllos) forest vegetation of rock outcrops, originally decribed by Chytrý \& Sádlo (1997). This species-rich community has grassy physiognomy of herb layer formed by Sesleria albicans, and is typically composed of mesophilous and thermophilous species of oak and oak-hornbeam forests, as well as plants of non-forests stands. It occurs on limestones or other base-rich bedrock of Bohemian massif, marginally reaching the northwestern part of the Pannonian region of Southern Moravia and Lower Austria (Chytrý \& Sádlo 1997, Chytrý 2013). In Austria, Willner \& Grabherr (2007) evaluated Seslerio albicantis-Tilietum cordatae as a synonym for Aceri platanoidis-Tilietum platyphylli. Ecological affinity of the association is similar to Seslerio heufleranae-Quercetum petraeae decribed from limestones in Slovenský kras Mts (southern part of Central Slovakia; Šomšák \& Háberová 1979). However, the species composition shows significant differences and both units can be considered as geographical vicariants linked to similar sites, what is in accordance with the findings of floristic comparison of the Central European Tilia-dominanted calcicolous forests (Chytrý \& Sádlo 1997). Our syntaxonomical concept partially overlaps with syntaxonomic schemas of scree and ravine forests in Ukraine and Poland (Onyschenko 2010, Matuszkiewicz et al. 2018), as well. Recently, Novák et al. (2017) reported the occurrence of similar communities from Transcarpathia (southern part of Ukrainian Eastern Carpathians) and classified them as Aceri-Tilietum, Arunco dioici-Aceretum pseudoplatani Moor 1952 and Phyllitido-Aceretum Moor 1945 (both as Lunario redivivae-Aceretum pseudoplatanii in our study). Austrian and Hungarian vegetation lists of scree and ravine communities are, on the contrary, different (Willner \& Grabherr 2007, Borhidi et al. 2012). To a certain extent it is due to the specific phyto- 
geography, ecological conditions (e.g. climatic characteristics), and historically different human activities in the Alps, compared to the Western Carpathians in Slovakia. Moreover, some plant communities of scree and ravine forests, which were described for the first time from Pannonian region, have been reported only from Hungary, especially ravine forests of colline and submontane zones (e.g. Mercuriali-Tilietum Zólyomi Jakucs in Zólyomi 1958, Parietario-Aceretum (Horánszky 1964) Soó 1971 (Borhidi et al. 2012). However, they don't seem to be geographically and ecologically distinct because they occupy similar habitats as those in other Central European mountain ranges. Therefore, other authors didn't recognise them at the rank of association in adjacent areas. To revise, reconcile and combine classification of these communities in the Central Europe, serious effort is needed using formalized approach and representative phytosociological dataset.

The latest checklist of vegetation units in Slovakia listed 10 associations of scree and ravine forests (Jarolímek \& Šibík 2008). We reduced this number to half because several of them were not reproduced in our numerical classification and were thus included as a synonym of currently accepted syntaxa, e.g. the species-poor block forest community of Roso pendulinae-Tilietum cardatae described by Csiky et al. (2001) from Cerová vrchovina Mts (southern part of central Slovakia). These stands are dominated by Tilia cordata, T. platyphyllos, Quercus petraea agg. with the co-occurrence of Acer campestre, A. pseudoplatanus, Carpinus betulus and Fagus sylvatica in tree layer. They usually have well-developed shrub layer (e.g. Euonymus verrucosus, Rosa pendulina) with high constancy of mesophilous and nitrophilous plants, ferns and thermophilous species of open habitats in herb layer (e.g. Dryopteris filix-mas, Geranium robertianum, Mycelis muralis, Polypodium vulgare, Poa nemoralis, Rubus idaeus, Hylotelephium maximum). The habitat preferences and spe- cies composition of the association clearly differ from similar thermophilous community described from Hungary Mercuriali-Tilietum (Csiky et al. 2001). However, authors did not compare the community with other thermophilous association (e.g. Aceri platanoidis-Tilietum platyphylli). Both nomenclatural type relevés (Aceri platanoidis-Tilietum platyphylli and Roso pendulinae-Tilietum cardatae) were grouped into one cluster, together with similar relevés from southern part of Slovakia (unpublished). Therefore, Roso pendulinae-Tilietum cardatae is quoted in the list of synonyms for Aceri platanoidis-Tilietum platyphylli.

Both alliances presented in our study are relatively well differentiated along the gradients of moisture, temperature, light and soil reaction. The alliance Melico-Tilion platyphylli represents stands growing on relatively dry, light, warmer sites with relatively low nutrient content, while stands of the alliance Tilio platyphylli-Acerion prefer habitats with opposite characteristics. Ecological requirements and also floristic composition fully correspond with recently used syntaxonomical concept: thermophilous lime forests on scree slopes at low altitudes of the southern regions of Central Europe (Melico-Tilion platyphylli) and sycamore maple forests in the montane belt and cool ravines of the Central European mountain ranges (Tilio platyphylli-Acerion; Mucina et al. 2016). It has been found that two associations are more distinct in ecological characteristics than others. First one, the forest stands of the Seslerio heufleranae-Quercetum petraeae, had significantly higher values of EIV for light and lower for soil nutrients compared to other associations. They occupy steep southern slopes leading to a sparse canopy of forest overstory with light-demanding and thermophilous tree species (Quercus petraea agg., Sorbus aria, $S$. torminalis). High occurrence of oak species in tree layer suggests their transition towards thermophilous oak-dominated forests (Kliment et al. 2010). Low values of soil nutrients are probably caused by soil type - skeletal 
rendzina on steep slopes (Šomšák \& Háberová 1979, Kliment et al. 2010), where fine soil particles are easily transported to lower horizons or even downslope leading to high stoniness of topsoil. This likely reduces amount of available nutrients for plants and may promote higher frequency of several plants with broad ecological niche (from slightly acidic to alkaline soils) such as Cruciata glabra, Galium schultesii, Rosa pendulina, Sorbus aucuparia. The second one, Lunario redivivae-Aceretum pseudoplatani was related to montane areas with the lowest temperature and highest precipitations. Mountainous character of these stands is reported across various European countries, but they also occur in inverse areas at lower altitudes with wetter and cooler mesoclimate (e.g. Willner \& Grabherr 2007, Chytrý 2013, Matuszkiewicz et al. 2018).

Some nomenclatural issues of the association Lunario redivivae-Aceretum pseudoplatani should be mentioned, as well. Although the generally used correct name for scree montane forests with dominance of Lunaria rediviva is Phyllitido-Aceretum Moor 1945, it was used only for a narrowly defined syntaxon for a long-time. Moreover, it is considered to be the synonym for Scolopendrio-Fraxinetum, which represents typical ravine forests of Melico-Tilion platyphylli (e.g. Moravec et al. 2000, Jarolímek \& Šibík 2008) and therefore, the use of the name Scolopendrio-Fraxinetum could be misleading. There are two other names that are older: Aceri-Fraxinetum (Gradm.) Tx. 37 and Aceri-Fraxinetum Koch 1926, but their use is not possible due to nomenclature reasons (see Chytrý 2013). In this sense, we propose to apply the name Lunario redivivae-Aceretum pseudoplatani Klika 1936 as an alternative (ICPN, article $3 \mathrm{j}$ ) for scree montane forests (750-1200 m a.s.1.) on carbonate and crystalline bedrock dominated by Acer pseudoplatanus and Fagus sylvatica (with the co-occurrence of Abies alba, Fraxinus excelsior and Picea abies) in tree layer and with dominance and/or high constancy of Lunaria rediviva and occasional presence of Phyllitis scolopendrium in herb layer (Klika 1936).

This new concept of Slovak syntaxonomical classification of scree and ravine forests based on numerical classification of representative dataset is rather clear due to the evident floristic and ecological differentiations at the association, as well as at alliance level. It provides a good basis for more consistent revision, mainly in case of thermophilous ravine and scree forests within Central and South-Eastern European region.

\section{Acknowledgements}

We are very grateful to J.-P. Theurillat, W. Willner, L. Mucina and F. Krahulec for their help to solve nomeclatural issues thanks to their expert knowledge and also for providing crucial publications. Further, we would like to thank to D. Senko for processing of climatic and geological data, E. Fajmonová, J. Kollár, P. Mráz, J. Ripka, M. Valachovič, K. Vantarová and H. Žarnovičan for providing unpublished data and I. Svitková for valuable comments to the manuscript. This research was supported by the Science Grant Agency of the Ministry of Education of the Slovak Republic and the Slovak Academy of Sciences VEGA, grants no. $2 / 0031 / 17$ and $1 / 0639 / 17$.

\section{References}

Baran J., Pielech R., Bodziarczyk J., 2018. No differences in plant species diversity between protected and managed ravine forests. Forest Ecology and Management 430: 587-593. DOI: 10.1016/j.foreco.2018.08.052

Borhidi A., Kevey B., Lendvai G., 2012. Plant communities of Hungary. Akadémiai kiadó, Budapest, 544 p.

Berta J., 1986. Lipovo-javorové lesy [Lime-maple Woods]. In Michalko J. (ed.), Geobotanická mapa ČSSR Slovenská socialistická republika. Veda, Bratislava, pp. 5961.

Campos J.A., Gacía-Mijangos I., Herrera M., Loidi I., Biurrun I., 2011. Ravine forests (Tilio-Acerion) in the Iberian Peninsula. Plant Biosystems 145: 172-179. DOI: $10.1080 / 11263504.2011 .602738$ 
Chytrý M. (ed.), 2013. Vegetation of the Czech Republic 4. Forest and scrub vegetation. Academia, Praha. 551 p.

Chytrý M., Sádlo J., 1997. Tilia-dominated calcicolous forests in the Czech Republic from a Central European perspective. Annali di Botanica 55: 105-126.

Chytrý M., Tichý L., 2003. Diagnostic, constant and dominant species of vegetation classes and alliances of the Czech Republic: a statistical revision. Folia Facultatis Scientiarum Naturalium Universitatis Masarykianae Brunensis, Biologia 108: 1-231.

Chytrý M., Tichý L., Holt J., Botta-Dukát Z. 2002. Determination of diagnostic species with statistical fidelity measures. Journal of Vegetation Science 13: 79-90. DOI: 10.1111/j.1654-1103.2002.tb02025.x

Csiky J., Kevey B., Borhidi A., 2001. Block forest (Roso pendulinae-Tilietum cordatae), a new forest community of the Carpathian basin (Cerová Vrchovina, Slovakia). Acta Botanica Hungarica 43: 95-125. DOI: 10.1556/ ABot.43.2001.1-2.5

Dierssen K., 1996. Vegetation Nordeuropas [Vegetation of Northern Europe]. Eugen Ulmer, Stuttgart, 838 p.

Ellenberg H., Weber H.E., Düll R., Wirth W., Werner W., Paulißen D. 1992. Zeigerwerte von Pflanzen in Mitteleuropa [Indicator values of plants in Central Europe]. 18: $1-258$

Faber A., 1936. Über Waldgesellschaften auf Kalksteinböden und ihre Entwicklung im Schwäbisch-Frankischen Stufenland aund auf der Alb [About forest communities on limestone soils and their development in the Svabian-Frankish Highlands and on the Albe]. Anhang zum Versammlungs-Bericht 1936 der Landesgruppe Württenberg des Deutschen Forstvereins, pp. $1-53$.

Fajmonová E., 1973. Prehl'ad sutinových lesov stredného Považia [A servey of ravine forests in the middle Váh river]. Biológia 28: 547-561.

Fajmonová E., 1974. Schutthaldenwälder des mittleren Einzuggebietes des Waag-Flusses [Ravine forests in the middle Váh river]. Acta Facultatis Rerum Naturalium Universitatis Comenianae, Botanica 22: 123-140.

Fajmonová E., 1980. K problematike zarad'ovania prechodných fytocenóz do klasifkačného systému na príklade spoločenstiev v Slovenskom raji [On the phytosociological classification of transitional phytocoenoses: an example of forest communities in the Slovak Paradise (Slovenský raj)]. Preslia 52: 227-239.

Fajmonová E., 1993. Výskyt zriedkavých spoločenstiev sutinových lesov v Strážovských vrchoch [Occurrence of rare communities of ravine forets in Strážovské vrchy mountains]. Biológia 48: 49-52.

Fischer H.S., 2015. On the combination of species cover values from different vegetation layers. Applied Vegetation Science 18: 169-170. DOI: 10.1111/avsc.12130

Háberová I., Dzubinová L., Fajmonová E., Jančová M., Karasová E., Lisická E., Petrík A., Rybárska V., Uhlířová J., Urvichiarová E., Vološčuk I., Zelinka J., 1985. Vegetácia krasových oblastí SSR z hl’adiska ochrany [Vegetation of karst area of SSR from nature conservation point of view. Partial final report.]. Čiastková záverečná správa. Prírodovedecká fakulta UK, Bratislava.

Hennekens S.M., Schaminée J.H.J., 2001. TURBOVEG, a comprehensive data base management system for vegetation data. Journal of Vegetation Science 12: 589-591. DOI: $10.2307 / 3237010$

Husová M., 1973. Die Schluchtwälder des Gebirges Hrubý Jeseník (Hohes Gesenke). Folia Geobotanica et Phytotaxonomica 8: 341-366. DOI: 10.1007/BF02852060

Jarolímek I., Šibík J. (eds), 2008. Diagnostic, constant and dominant species of the higher vegetation units of Slovakia. Veda, Bratislava, $332 \mathrm{p}$.

Jurko A., 1975. Waldgesellschaften des Zentralteiles des Ostslowakei und einige Fragen ihrer Syntaxonomie [Forest communities of the central part of Eastern Slovakia and some questions about their syntaxonomy]. Biologické Práce 21(3): 9-81.

Kącki Z., Czarniecka M., Swacha G., 2013. Statistical determination of diagnostic, constant and dominant species of the higher vegetation units of Poland. Monographiae Botanicae 103: 1-272. DOI: 10.5586/ mb.2013.001

Klika J., 1936. Das Klimax-Gebiet der Buchenwälder

in der Westkarpathen [Beech climax area in Western Carpathinas]. Beihefte zum Botanischen Centralblatt 55B: 373-418.

Klika J., 1941. Rostlinosociologická studie křivoklátských lesů [Forests of Krrivoklát. Phytosociological study]. Věstník Královské České Společnosti Nauk, Tř. Mat.Př́r. 1941/3: 1-46.

Klika J., 1942. Rostlinně-sociologický příspěvek k poznání Prešovských kopců [Forests of Prešov hills. Phytosociological study]. Věstník Královské České Společnosti Nauk, Tř. Mat.-Př́r. 1942/17: 1-25.

Klika J., 1955. Nauka o rostlinných společenstvech (Fytocenologie) [Study about plant communities (phytosociology)]. Nakladatelství Československé akademie věd, Praha, 360 p.

Kliment J., Ujházy K., Ujházyová M., Hrivnák R., Kochjarová J., Blanár D., 2010. Syntaxonómia bukových a sutinových lesov južnej časti Muránskej planiny [Syntaxonomy of beech and scree forests in the southern part of the Muránska planina Mts]. Bulletin Slovenskej Botanickej Spoločnosti 32, Suppl. 2: 161-211.

Košir P., Čarni A., Di Pietro R., 2008. Classification and phytogeographical differentiation of broad-leaved ravine forests in southeastern Europe. Journal of Vegetation Science 19: 331-342. DOI: 10.3170/2008-8-18372

Marhold K., Hindák, F. (eds.), 1998. Checklist of non-vascular and vascular plants of Slovakia. Veda, Bratislava, $687 \mathrm{p}$.

Matuszkiewicz W., 2014. Przewodnik do oznaczania zbiorowisk roślinnych Polski [Plant communities of Poland]. Wydawnictwo Naukowe PWN, Warszawa, $537 \mathrm{p}$.

Matuszkiewicz W., Sikorski P., Srwed W., Wierzbu M., 
2018. Zbiorowiska roślinne Polski [Plant communities of Poland. Forests and scrubs.]. Lasy i zarośla. Wydawnictwo Naukowe PWN SA, Warszawa, 518 p.

Miadok D., 1981. Schuttwälder des nordwestlichen Teiles des Gemerské rudohorie-Gebirges. Acta Facultatis Rerum Naturalium Universitatis Comenianae, Botanica 28: $1-18$.

Miklós L (ed.), 2002. Landscape Atlas of the Slovak Republic. Ed. 1. Ministry of Environment of the Slovak Republic, Bratislava \& Slovak Environmental Agency (Banská Bystrica), 344 p.

Moravec J., Husová M. Neuhäusl R., Neuhäuslová-Novotná Z., 1982. Die Assoziationen mesophiler und hygrophiler Laubwälder in der Tschechischen Sozialistischen Republik [The associations of the mesophilous and hygrophilous deciduous forests inthe Czech Socialist Republic.]. Academia, Praha, 295 p.

Moravec J., Husová M., Chytrý M., Neuhäuslová Z., 2000. Přehled vegetace České republiky. Svazek 2. Hygroflní, mezoflní a xeroflní opadavé lesy [Vegetation survey of the Czech Republic. Volume 2. Hygrophilous, mesophilous and xerophilous deciduous forests.]. Academia, Praha, 319 p.

Morton A., 2005. DMAP for Windows. Software for Distribution Mapping, Version 7.2. URL: http://www. dmap. co.uk/.

Mucina L., Bültmann H., Dierßen K., Theurillat J-P., Raus T., Čarni A., Šumberová K., Willner W., Dengler J., García R.G., Chytrý M., Hájek M., Di Pietro R., Iakushenko D., Pallas J., Daniëls F.J.A., Bergmeier E., Guerra A.S., Ermakov N., Valachovič M., Schaminée J.H.J., Lysenko T., Didukh Y.P., Pignatti S., Rodwell J.S., Capelo J., Weber H.E., Solomeshch A., Dimopoulos P., Aguiar C., Hennekens S.M., Tichý L., 2016. Vegetation of Europe: hierarchical floristic classification system of vascular plant, bryophyte, lichen, and algal communities. Applied Vegetation Science 19 (suppl. 1): 3-264. DOI: 10.1111 /avsc. 12257

Mucina L., Maglocký Š. (eds), 1985. A list of vegetation units of Slovakia. Documents Phytosociologie 9: 175200.

Novák P., Zukal D., Večeřa M., Pišt'ková K., 2017. Vegetation of oak-hornbeam, scree and ravine forests at lower altitudes in Transcarpathia, Western Ukraine. Tuexenia 37: 47-63.

Onyshchenko V., 2010. A revised classification of Ukrainian forests of the order Fagetalia sylvaticae. Tuexenia 30: 31-45.

Paal J., 2009. The forests of the North-Eastern Estonian Klint: the north-easternmost representatives of the EU Habitat Directive Tilio-Acerion forests of slopes, screens and ravines. Annales Botanici Fennici 46: 525540. DOI: $10.5735 / 085.046 .0605$

Pott R., 1992. Die Pflanzengesellschaften Deutschlands [Plant communities of Germany]. Eugen Ulmer, Stuttgart, $427 \mathrm{p}$.

R Core Team, 2013. R: A language and environment for statistical computing. R Foundation for Statistical Com- puting, Vienna, Austria. URL http://www.R-project. org/.

Rodwell J.S. (ed.), 1991. British plant communities. Vol. 1.Woodlands and scrub. Cambridge University Press, Cambridge, $408 \mathrm{p}$.

Roleček J., Tichý L., Zelený D., Chytrý M., 2009. Modified TWINSPAN classification in which the hierarchy respects cluster heterogeneity. Journal of Vegetation Science 20: 596-602. DOI: 10.1111/j.16541103.2009.01062.x

Šibík J., 2012. Slovak Vegetation Database. In Dengler J., Oldeland J., Jansen F., Chytrý M., Ewald J., Finckh M., Glöckler F., Lopez-Gonzalez G., Peet R.K., Schaminée J.H.J. (eds), Vegetation databases for the 21 st century. Biodiversity and Ecology 4: 429-429.

Šomšák L., Háberová I., 1979. Die Waldgesellschaften des Silica-Plateaus [Forest communities of Silica plain]. Biologické Práce 25: 5-89.

Schwickerath M., 1938. Wälder und Waldböden des Hohen Venns und seiner Randgebiete [Forests and forest soils of Hohen Venns upland area and her foothills]. Mitteilungen aus Forstwitschaft und Forstwissenschaft 3: 261-350.

Ter Braak C.J.F., Šmilauer P., 2012. CANOCO reference manual and user's guide: software for ordination (version 5.0). Microcomputer Power. Ithaca, $496 \mathrm{p}$.

Tichý L., 2002. JUICE, software for vegetation classification. Journal of Vegetation Science 13: 451-453. DOI: 10.1111/j.1654-1103.2002.tb02069.x

Tichý L., Chytrý M., 2006. Statistical determination of diagnostic species for site groups of unequal size. Journal of Vegetation Science 17: 809-818. DOI: 10.1111/ j.1654-1103.2006.tb02504.x

Ujházyová M., 2007. Syntaxonómia bukových lesov na vápencoch bradlového pásma [Syntaxonomy of beech forests on the limestone of klippen belt]. Technická univerzita, Zvolen, $151 \mathrm{p}$.

Vukelić J., 2012. Šumska vegetacija Hrvatske [Forest vegetation of Croatia]. Šumarski fakultet, Zagreb, 403 p.

Wallnöfer S., Mucina L., Grass V., 1993. Querco-Fagetea. In Mucina L. (ed.), Die Pflanzengesellschaften Österreich. Teil 3. Wälder und Gebüsche [Plant communities of Austria. Volume 3. Forests and scrubs]. Gustav Fischer, Jena, pp. 85-236.

Weber H.E., Moravec J., Theurillat J.-P., 2000. International Code of Phytosociological Nomenclature. 3rd edition. Journal of Vegetation Science 11: 739-768. DOI: $10.2307 / 3236580$

Willner W., 1996. Die Gipfeleschenwälder des Wienerwaldes [Ash-dominated forests on mountain peaks in the "Wienerwald" (Eastem Austria)]. Verh. Zool.-Bot. Ges. Österreich 133: 133-184.

Willner W., 2015. Proposal (20): to conserve the name Aceretalia pseudoplatani Moor 1976 against Tilietalia Moor 1973. Phytocoenologia 45: 185-186. DOI: 10.1127/phyto/2015/0051

Willner W., Grabherr G., 2007. Die Wälder und Gebüsche Österreichs. Ein Bestimmungswerk mit Tabellen 
[The forests and scrubs of Austria]. Spektrum Akademischer Verlag, Heidelberg, 608 p.

Zelený D., Schaffers A.P., 2012. Too good to be true: pitfalls of using mean Ellenberg indicator values in vegetation analyses. Journal of Vegetation Science 23: 419431. DOI: 10.1111/j.1654-1103.2011.01366.x

\section{Supporting Information}

The online version of the article includes Supporting Information:
Supp. Info. 1. List of plant species merged to aggregates (agg.), broadly defined taxa (s. lat.) or genus level (sp. div.) in the data set.

Supp. Info. 2. List of the literature sources (author, abbreviated reference, number of relevés).

Supp. Info. 3. Abbreviations of plant taxa in Figure 3.

Supp. Info. 4. Phytosociological Tables 1-3. 